\title{
THE DUGOUTS/OUR BLUE ANGEL
}

for L.Z. \& A.V.

The lines of this new poem are everything like not seeing the ghost in the field, again.

I have an obscure, provocative French bicycle, and accidents. I have new pink

skin on my knees, again. In the poplars the spikes of the catkins twirl

like the spokes of a wheel, like the tassels on the breasts of a girl who

travels this ellipse which in its trajectory disputes the lines of my new poem

which is nothing. Though, the sum of its distances from two fixed points

is arousing and familiar like the joy of seeing the ghost in the field, again.

\section{On Norman Dubie’s Poems}

\section{Jon Anderson}

I read poems, most immediately \& personally, on two levels. The first is empathetic; I'm fascinated with what James Agee calls "the mystery and weight and dignity" of other lives. Every poem, no matter how mannered, is a human voice which longs for company. Here, poems gather around sentences which are personal revelation and books around those poems which are most authentic. I like some poems \& many books on this basis: that, ultimately, their style \& content are imbued with the poet's character. Like every experience that alters me, they are intimate.

But a second sensibility enters here: the ultimate variety \& boredom of response to other lives asks that I respect the poet's professionalism. This aesthetic judgment is the more personal one. I want a poem to be a serious entertainment; 